\title{
The Authoritarian Predisposition, Perceived Threat, and Trust in Political Institutions
}

-Kris Dunn, School of Politics and International Studies, University of Leeds

\begin{abstract}
The more authoritarian an individual, the more socio-culturally conservative their attitudes and the more they yield to authority. The more authoritarian should, therefore, be more supportive of political institutions than their more libertarian counterparts. Building on recent research, I further hypothesize that differences across authoritarianism in support for political institutions will narrow among those who perceive greater threat. Utilizing data from the World Values Survey, I conduct a series of multilevel analyses examining the relationship between authoritarianism and confidence in the armed forces, police, parliament, government, and courts, conditional on perceived threat. The results demonstrate the more authoritarian are more trusting of political institutions and this relationship is, for some institutions, conditional on perceived threat. These findings add to our understanding of how values orientations can affect individual trust in government institutions and why support for more aggressive solutions to societal problems may dominate when perceived threat becomes more commonplace.
\end{abstract}

Keywords: Authoritarian Predisposition; Libertarian Dynamic; Perceived Threat; Political Trust 
The authoritarianism literature emerged from a concern with how democratic governance can destabilize and collapse due to public support for anti-democratic forces. Some of this early research focused on why people seemingly blindly submit to authorities. Fromm (1941) stresses that the modern world fosters a sense of aloneness and powerlessness and that many would happily submit to any authority that promises escape from such feelings. Frenkel-Brunswik et al. (1947) similarly argue that societies create various personality types, one of which, the antidemocratic personality (later renamed the authoritarian personality (Adorno, Frenkel-Brunswik, Levinson, \& Sanford, 1950)), is prone to “a highly moralized and idealized conception of authority-representatives and a submissive relation to them” (p. 641) (p. 641) (p. 641) (p. 641). The concern with submission to authority carried through to more recent research thanks to the work of Altemeyer (e.g., 1996). However, since then, the concern with authority-relations in authoritarianism research has faded somewhat, secondary to concerns with intolerance.

In this article, I revisit the idea of political authority-relations in the context of recent adjustments to the conceptualization of authoritarianism found in the work of Feldman and Stenner (Feldman, 2003; Feldman \& Stenner, 1997; Stenner, 2005) and Hetherington and colleagues (Hetherington \& Suhay, 2011; Hetherington \& Weiler, 2009). In the following discussion, I examine what this recent reconceptualization has to say about authority-relations and how this relates to trust in political institutions. I test four hypotheses derived from this discussion with multilevel analyses of data from the sixth wave of the World Values Survey.

\section{The Authoritarian Predisposition}

Authoritarianism is a values orientation concerned with the trade-off between social conformity and individual autonomy (Feldman, 2003; Stenner, 2005). More authoritarian 
individuals prioritize social conformity over individual autonomy while more libertarian ${ }^{1}$ individuals prioritize individual autonomy over social conformity. Those with a relative preference for social conformity values, authoritarians, will express more socially conservative attitudes as they prioritize tradition and conformity (cf., Schwartz, 2012) while those with a relative preference for individual autonomy values will express more socially liberal attitudes as they prioritize stimulation and self-direction.

Hetherington and Weiler (2009) imply that authoritarianism is rooted in, or at least strongly related to, sensitivity to group threat. The more sensitive one is to threat to the wellbeing of their ingroup, the more authoritarian one is; the less sensitive one is to threat to the wellbeing of the ingroup, the more libertarian one is. Prioritizing social conformity over individual autonomy ensures that the group is unified and capable of decisively responding to such threat, thereby securing the wellbeing of the group (Duckitt, 1989; Feldman, 2003). Those who feel more secure in their environment and are less concerned with threat to ingroup wellbeing are

\footnotetext{
${ }^{1}$ There is tension in the authoritarianism literature on whether to refer to the opposite pole from an authoritarian (pre)disposition as a libertarian (pre)disposition or a non-authoritarian (pre)disposition. Foundational researchers in this area refer to this pole as libertarianism (Duckitt, 1989; Feldman \& Stenner, 1997) for the simple reason that a low authoritarianism score does not just imply an absence of authoritarianism, but also the presence of something else. As authoritarianism is a trade-off between two value sets - social conformity values and individual autonomy values - a high score on the opposite pole from authoritarianism is indicative of both a very low preference for social conformity values and a very high preference for individual autonomy values. As Duckitt (1989) notes, use of the term 'non-authoritarian' leaves the opposite pole from authoritarianism in a metaphorical limbo, ungrounded in any concept of what the opposite of authoritarianism actually involves. Utilizing the term 'libertarianism' to anchor this opposite pole anchors this pole to those values concerned with human autonomy.
} 
more likely to prioritize individual autonomy over social conformity (cf., Dunn, Griffiths, Lamb, Shortt, \& Theochari, 2017). More explicitly, Hetherington and Weiler (2009) argue that the more authoritarian one is, the more likely one is to perceive group threat as a matter of course. This is not to say that the more libertarian do not perceive threat, merely that they are not as sensitive to potential threats.

To this point, there is little difference between earlier, attitudinal models of authoritarianism (e.g., Altemeyer, 1996; Duckitt, 1989) and later, values-based models (e.g., Feldman \& Stenner, 1997; Hetherington \& Weiler, 2009). Both models consider the more authoritarian to be more responsive to threat and both predict socially conservative attitudes. However, while earlier models consider an authoritarian disposition and authoritarian response as part and parcel of same concept, the latter consider the predisposition to respond and the actual response as separate concepts; the predisposition to respond is labeled an authoritarian (or libertarian) predisposition and the response is labelled according to qualities of the attitudes (e.g., social conservatism). This difference has important consequences for the role of threat.

\section{The Authoritarian Predisposition and Threat}

In earlier models of authoritarianism, threat was primarily considered causal to the disposition (Duckitt, 2013). In contrast, the authoritarian predisposition is an inclination to respond to threat to the ingroup by adopting a particularly defensive set of attitudes (Hetherington \& Weiler, 2009).

Threat can induce or increase feelings of anxiety and fear (cf., Riskind, 1997). Beyond a tolerable threshold, we begin to seek out ways to reduce these feelings to maintain our emotional and physical wellbeing. Adopting socially conservative attitudes is one pathway to reduce 
anxiety and fear (Bonanno \& Jost, 2006; Jost, Glaser, Kruglanski, \& Sulloway, 2003; Jost et al., 2007; Matthews, Levin, \& Sidanius, 2009; McLaren, 2003; Nail, McGregor, Drinkwater, Steele, \& Thompson, 2009; Riek, Mania, \& Gaertner, 2006). When one perceives a threat to the wellbeing of their ingroup, they become more protective of their ingroup (Duckitt, 1989) and in so doing, become more intolerant and aggressive toward perceived difference and violation of group norms (Stenner, 2005).

Though this reaction seems universal (e.g., Gadarian, 2010; Huddy, Feldman, Taber, \& Lahav, 2005), the authoritarian predisposition distinguishes between those who are more or less prone to a generalized, as opposed to a specific, sense of threat (cf., Oesterreich, 2005).

Generalized threat is a nebulous sense that there is some current or impending danger to the wellbeing of the ingroup. Hetherington and Weiler (2009) imply that it is generalized threat that keeps authoritarians "manning the barricades" (Stenner, 2005) as a matter of routine. The more authoritarian are more prone to this more generalized, nonspecific sense of threat. This is not to say that the more authoritarian do not perceive threats from specific sources or that they cannot identify a specific threat to their ingroup, only that there is always a threat to their ingroup regardless of any specific threat they may or may not be able to point to at present. This echoes Altemeyer's (1996) finding that the more authoritarian are also more likely to claim a whole host of 'most important problems'; if threat to group wellbeing is everywhere, finding a label for it or a specific example of it is unlikely to be problematic.

Specific threat, then, is also related to authoritarianism. For authoritarians, whose sense of generalized threat is purportedly rather high, it takes very little for any specific referent to appear threatening as their higher level of generalized threat causes them to perceive any potential specific threat as more threatening than it may otherwise be. For the more libertarian, 
lower generalized threat provides a lower baseline of threat capable of fueling the perception of specific threat. The more libertarian are therefore less likely to see potential threats as actually threatening.

Authoritarianism, then, is most notably manifest in an individual's default state of being: the most authoritarian are highly sensitive to anything that may threaten their group's wellbeing; the more libertarian are less so. In the absence of any specific threat, the more authoritarian nevertheless perceive a higher level of generalized threat to their ingroup and are therefore more socially conservative as a matter of course. ${ }^{2}$ In the absence of any specific threat, the more libertarian generally perceive little, if any, generalized group threat and are therefore more socially liberal. As perceived specific threat increases for the more libertarian, the differences in attitudes between authoritarians and libertarians fade as their perceived threat equalizes and their need to reduce their sense of anxiety increases (Hetherington \& Weiler, 2009).

\section{The Authoritarian Predisposition and Trust in Political Institutions}

The early scholarship on authoritarianism sought to understand why people would support the unravelling of democratic institutions and submit to illiberal and undemocratic institutional structures. Though this early research failed to accumulate much reliable evidence, the idea that authoritarians are more submissive to certain types of authorities is still a widely

\footnotetext{
${ }^{2}$ There are two important caveats to this point. First, Stenner (2005) demonstrates that authoritarians are capable of feeling that their ingroup is secure and, when such is the case, express similarly low levels of intolerance and punitiveness as libertarians. Second, while authoritarians are more socio-culturally conservative on average (Dunn et al., 2017), expressed intolerance is relative to the local social and political environment and decreases as countries become more democratic (Dunn, 2014; Dunn \& Singh, 2014). Therefore, while authoritarians are more socioculturally conservative on average, the degree is relative to local norms.
} 
accepted hypothesis (e.g., Altemeyer, 2004; MacWilliams, 2016; Stenner, 2005). Though this research tends to focus on submission to illiberal or undemocratic authorities, theory does not insist that authoritarians will only submit to non-democratic authorities: Altemeyer (1996) is careful to note the relevance of perceived legitimacy while Duckitt (1989) explicitly notes the importance of social identity. The relationship between authoritarianism and political authority is perhaps best summed up in Altemeyer's (1996) description of authoritarian submission as a "high degree of submission to the authorities who are perceived to be established and legitimate in the society in which one lives." The type of authority, then, whether autocratic or democratic, illiberal or liberal, is beside the point. The relevant aspect is whether the authority is perceived to be legitimate (cf., Tyler, 1997; Tyler \& Lind, 1992). Providing some evidence on this point, Dunn (2015) finds that in some countries, authoritarians support liberal parties over their more illiberal challengers.

As noted in previous research, those who score relatively highly in social conformity values are more likely to trust established political institutions as these institutions serve to maintain social order. They are particularly likely to trust those institutions perceived to "play a key role in the preservation and transmission of traditions and customs and assure the stability and continuity of society" (Devos, Spini, \& Schwartz, 2002, p. 492). On the other hand, those who score highly in individual autonomy values are more skeptical and critical of those institutions as they "restrain individuals' actions or impulses and limit their autonomy and ability to choose their own goals" (Devos et al., 2002, p. 492). Therefore, those who prioritize social conformity, authoritarians, are more likely to trust political institutions that propagate tradition and assure stability than are those who prioritize individual autonomy, libertarians. 
However, this relationship is likely to be conditional on perceived threat. Hetherington and Weiler (2009) demonstrate that when perceived threat increased following the September $11^{\text {th }}$ terrorist attacks in the United States, trust in President George W. Bush increased substantially among libertarians while authoritarians, who largely trusted President Bush to begin with, remained fairly static. In the same way that libertarians become more protective of their ingroup and hostile toward outgroups when they feel threatened, they will also become more trusting of legitimate authorities, particularly those institutions whose reason for being is to secure the wellbeing of the ingroup against threats.

Given the consequences of authority relations, understanding this relationship is critical to understanding how changes in perceived threat can impact the functioning and well-being of any given society. Trust in political institutions are necessary for efficient and effective governance. Political trust is predictive of (dis)satisfaction with political leaders (Hetherington, 1998), political participation (Hooghe \& Marien, 2013), voting behavior (Hetherington, 1999; Hooghe, Marien, \& Pauwels, 2011), policy support or opposition (Chanley, 2002; Hetherington, 2005; Hetherington \& Rudolph, 2015; Zhang \& Wang, 2010), compliance with government regulations (Marien \& Hooghe, 2011), and even with interpersonal trust, which in turn "promotes a productive economy, a more peaceful and cooperative society, and a democratic government" (Levi \& Stoker, 2000). How we interact with our political institutions and what, collectively, we allow them to do to or for us is a function of the trust we hold toward those institutions.

\section{Hypotheses}

The above discussion suggests the following hypotheses regarding the relationship between authoritarianism, perceived threat, and trust in political institutions: 
$\mathrm{H}_{1}$ : Authoritarianism is positively related to trust in political institutions.

$\mathrm{H}_{2}$ : There is a negative interaction between authoritarianism and threat in predicting trust in political institutions. ${ }^{3}$

$\mathrm{H}_{3}$ : The more libertarian will drive the negative interaction noted in $\mathrm{H}_{2}$.

$\mathrm{H}_{4}: \mathrm{H}_{2}$ and $\mathrm{H}_{3}$ will only apply to those institutions whose reason for being is to protect the ingroup from threat.

\section{Method}

\section{Sample}

This research proposes a general pattern that should be found across societies. In order to test these hypotheses across societies, the following analyses utilize hierarchical data (individuals embedded in countries) from the sixth wave of the World Values Survey (WVS 6 ; Inglehart et al. 2014). However, given the large discrepancies in the purpose and stability of political institutions between democratic and non-democratic countries (cf., Lagacé \& Gandhi, 2015), I focus here on those countries that were classified by Freedom House as 'free' at the time the survey was administered in that country (Freedomhouse.org, 2018). This data allows me to examine the effects of the interaction between authoritarianism and threat on trust in various political institutions across a wide variety of democratic political and social contexts.

The WVS draws a representative sample of at least 1000 respondents between the ages of 18 and 85 for each surveyed country. ${ }^{4}$ Full probability sampling is done where resources allow;

\footnotetext{
${ }^{3}$ A negative interaction indicates that the effect of libertarianism on trust will decrease as threat increases.

${ }^{4}$ Some countries include 16 and 17 year olds in their samples.
} 
otherwise, strictly governed quota sampling or some combination of probability and quota sampling is used. Interviews are conducted face-to-face. The $\mathrm{WVS}_{6}$ conducted surveys in 60 countries from around the world between the years 2010 and 2014. Excluding those countries not classified as 'free' by Freedom House and those with missing data relevant to testing the above hypotheses reduces the sample used here to 25 countries $^{5}$ with an average of 1,241 respondents per country.

\section{Measures}

Trust in Political Institutions: The dependent variables in this study are five questions that inquire as to the respondent's confidence in various political institutions: the armed forces, the courts, the government, the parliament, and the police. The courts, government, and parliament represent the primary branches of government (judicial, executive, and legislative), while the armed forces and police, though also aspects of the executive branch, represent the more overtly coercive side of government. These items indicate trust in regime institutions (cf., Easton, 1975; Norris, 1999b).

The survey instrument provides respondents with four response categories for each institution: no confidence, not very much confidence, quite a lot of confidence, and a great deal of confidence. Due to concerns with how well these categories, particularly the latter two, translate both distinction and degree of difference across individuals, languages, and cultures, I choose collapse the four categories into two: low trust, combining the 'no' and 'not very much'

\footnotetext{
${ }^{5}$ The countries included in this study are: Argentina, Australia, Brazil, Chile, Cyprus, Estonia, Germany, Ghana, India, Japan, Netherlands, New Zealand, Peru, Philippines, Poland, Romania, Slovenia, South Africa, South Korea, Spain, Sweden, Taiwan, Trinidad and Tobago, United States, and Uruguay.
} 
categories, and high trust, combining the 'quite a lot' and 'a great deal' categories, coded as 0 and 1 , respectively.

Ample previous work combines similar indicators to these into a single continuous scale of political or institutional trust (e.g., Marien \& Hooghe, 2011; Weiner \& Federico, 2017; Ziller \& Schübel, 2015). Such a strategy could arguably be acceptable here: exploratory country-bycountry factor analyses indicate acceptable loadings (0.4) on a single factor (though see André, 2014; Schneider, 2017), though in two countries the army item loaded at just about 0.3 , and most (18 of 25) Cronbach alphas surpass conventional acceptability (0.7) with the remainder all surpassing 0.6 .

However, $\mathrm{H}_{4}$ proposes variation in how the interaction between authoritarianism and threat will predict trust in the different institutions. This hypothesis is based on the premise that libertarians will express more trust during times of threat for those institutions that they view as capable of mitigating the relevant threat. The threat measure used in this research (see below) is largely a measure of existential threat stemming from physical conflict (e.g., war, terrorism). Of those institutions considered here I suspect three are likely candidates to demonstrate a libertarian dynamic (an interaction effect between authoritarianism and threat predominantly driven by the more libertarian): government, the armed forces, and the police. All three of these institutions are part of the executive branch of government and are therefore associated with acting against particularly threats. The armed forces and the police have the most direct and visible role to play as they are the frontline institutions intended to deal with societal threat. The government and parliament are more indirect actors, dictating policy and legislation in response to such events; however, they are likely to be in the public eye when societal threats are salient issues. The courts, on the other hand, are less directly involved, at least in initial social and 
political responses to threat, and unlikely to be a focal institution during threatening events. Analyses of the armed forces and the police are therefore the most likely to indicate a libertarian dynamic. Analyses of the parliament and the government may also indicate a libertarian dynamic. It is unlikely that analyses of the courts will indicate a libertarian dynamic. $\mathrm{As}_{4}$ can only be investigated by maintaining separate indicators, I retain each of the five indicators as separate measures.

Authoritarianism: This article conceptualizes authoritarianism as a values orientation concerned with the trade-off between social conformity and individual autonomy. Similarly to Dunn et al. (2017) and Arikan and Sekercioglu (2019), I utilize Feldman's (2003) SCA-V (social conformity - autonomy values) approach to measure authoritarianism. This scale is constructed using items from the WVS's shortened version of the Portrait Values Questionnaire (Schwartz et al., 2001).

Schwartz and colleagues' related measures of basic human values have been validated in hundreds of samples across dozens of diverse countries: 10 values form a reliable and valid quasi-circumplex structure (e.g., Bilsky et al., 2015; Cieciuch, Davidov, Algesheimer, \& Schmidt, 2018; Maio, Pakizeh, Cheung, \& Rees, 2009; Schwartz, 1992, 2007; Schwartz \& Bilsky, 1987; Schwartz \& Boehnke, 2004; Schwartz et al., 2012; Schwartz et al., 2001). Of particular interest here are those values utilized by Feldman in his SCA-V scale: self-direction, stimulation, conformity, and tradition. Schwartz (2012) considers the driving goal of selfdirection to be "independent thought and action" requiring "autonomy and independence". The driving goal of stimulation is "excitement, novelty, and challenge in life", similarly requiring autonomy and independence. The value of conformity is associated with a desire to restrain "actions, inclinations, and impulses likely to upset or harm others and violate social expectations 
or norms" requiring that individuals "inhibit inclinations that might disrupt and undermine smooth interaction and group functioning." The defining goal of tradition is the "respect, commitment, and acceptance of the customs and ideas that one's culture or religion provides", similarly requiring that individuals "[subordinate] the self to socially imposed expectations." Importantly, stimulation and self-direction values and conformity and tradition values cluster together in all samples and are consistently found to fall opposite each other on the valuescircumplex reinforcing the often-referenced tension between individual autonomy and social conformity values (Feldman, 2003).

To create this measure, I first average each individual's scores on the stimulation ("Adventure and taking risks are important to this person; to have an exciting life") and selfdirection ("It is important to this person to think up new ideas and be creative; to do things one's own way") items to produce the individual autonomy index and average the conformity ("It is important to this person to always behave properly; to avoid doing anything people would say is wrong") and tradition ("Tradition is important to this person; to follow the customs handed down by one's religion or family") items to produce the social conformity index. Each index ranges from 1 to 6 with a higher score indicating a higher reported identification with that value cluster. I then subtract the individual autonomy index from the social conformity index producing an authoritarian predisposition scale ranging from -5 to +5 . Those scoring below 0 , the midpoint of the scale, prioritize individual autonomy over social conformity; those who score above 0 prioritize social conformity over individual autonomy. Those who score precisely 0 prioritize neither and can be said to be either ambivalent or indifferent (Dunn \& Thornton, 2019). Higher scores on this scale indicate a greater degree of authoritarianism, while lower scores indicate a greater degree of libertarianism. 
Analyses of a baseline two-factor pooled version of this model conducted by Dunn, Spaiser, and Dodds (2020) on the WVS $_{6}$ data (conducted using 54 countries which include those 25 used here), indicate a good model fit, reporting a CFI of 0.998 and a RMSEA of 0.021 . A two-factor multi-group model, specifically accounting for the hierarchical nature of the data and explicitly testing for configural invariance (i.e., the same variables loading on the same latent constructs across countries) also indicates an acceptable model fit, reporting a CFI of 0.987 and a RMSEA of 0.064. While the fit indicators do decrease from the pooled to the multi-group model, combined with the above-noted analyses of the Portrait Values Questionnaire, Dunn et al.'s (2020) analyses indicate that this particular measurement model of the authoritarian predisposition does measure an equivalent concept across countries. ${ }^{6}$

Perceived Threat: The literature on authoritarianism frequently mentions threat and even, occasionally, specifies the type of threat under consideration (Feldman, 2013). Theory on what type of threat should provoke a reaction from those across the authoritarianism scale varies with measures accounting for both normative (Stenner, 2005) and existential threat (Hetherington \& Suhay, 2011) and both collective (Doty, Peterson, \& Winter, 1991; Sales, 1973) and personal threat (Cohrs, Kielmann, Maes, \& Moschner, 2005). I consider the threat measure used here to be a measure of collective, existential threat. ${ }^{7}$

\footnotetext{
${ }^{6}$ Measures of internal consistency do not apply to this formative construct and so are not reported here. Though the items combine to form a single construct, this construct is a combination of four different values and therefore should not be internally consistent.

${ }^{7}$ The most appropriate classification for particular threats is not always entirely clear (cf., Asbrock \& Fritsche, 2013; Feldman, 2013). This measure could also address a more normative and personal perspective.
} 
The $\mathrm{WVS}_{6}$ features a series of questions which ask about the degree to which the respondent is worried about six distinct events: "Losing my job or not finding a job", "Not being able to give my children a good education", "A war involving my country", "A terrorist attack", "A civil war", and "Government wire-tapping or reading my mail or email". Respondents are given four response categories: "Not at all”, "Not much”, “A good deal”, "Very much”. Analyses by Dunn et al. (2020) indicate that the latter four items combine to form a valid threat scale demonstrating acceptable goodness-of-fit scores for a model of configural invariance (RMSEA = 0.064, CFI $=0.993$ ); the first two items substantially worsen the model fit and are therefore dropped from the scale. This four-item measure also demonstrates a high level of internal reliability; analyses conducted specifically on this sample indicate Cronbach's alphas exceeding the standard requisite of 0.70 in all 25 countries. I therefore average the war, terrorist attack, civil war, and wire-tapping items into a single perceived threat scale recoded to range from 0 to 1 with higher values corresponding with higher perceived threat.

Control variables: The following analyses control for basic demographics - age, education, income, and sex. Age is a direct report of the respondent's age, rescaled to range from 0 to 83 (i.e., age $=$ age -16 ). Education is a variable resulting from a question inquiring in to the respondent's highest level of education; ranging from 0 (no formal education) to 6 (universitylevel education, with degree). Income is a measure of the respondent's income level in terms of country-specific income scales ranging from 0 to 9 with a higher number indicative of a higher income. Sex is coded by the interviewer as male (0) or female (1) based on their observation of the respondent. 


\section{Results}

As this research aims to draw broad, non-country specific conclusions regarding the hypothesized relationships hypothesized above, and as the dependent variables are all binary, indicating either low or high trust, the following analyses use a logistic multilevel framework with individuals embedded in countries. Null models of each dependent variable and the likelihood-ratio test of rho $=0$ for each full model indicate that the country-level variance component is meaningful. Country-level factors explain $15 \%$ of the variance in confidence in the armed forces, $17 \%$ for confidence in the courts, $13 \%$ for confidence in the government, $15 \%$ for confidence in the parliament, and $15 \%$ for confidence in the police. A multilevel framework is therefore necessary to account for the non-independence of within-country observations.

As $\mathrm{H}_{4}$ proposes a potential difference in the relationship between authoritarianism, perceived threat, and trust across the different institutions, the analyses will focus on one institution at a time dealing first with the core branches of government and then with the subexecutive institutions.

\section{Trust in the Courts}

Table 1 presents two models predicting trust in the courts. The left-most model displays the output from a multilevel logit model predicting high trust in the courts. This model presents the additive effects of authoritarianism and threat, controlling for demographics. Supporting $\mathrm{H}_{1}$, authoritarianism is positively related to trust in the courts. At authoritarianism's lowest value (5 ), the probability of expressing high trust in the courts is 0.452 , increasing to 0.524 when authoritarianism $=0$ and 0.594 when authoritarianism is at its highest value (5). Increasing from the lowest to the highest level of authoritarianism corresponds to a 0.142 increase in the probability of reporting a high level of trust in the courts. 


\begin{tabular}{lcccccc}
\hline \hline \multicolumn{4}{c}{ Table 1: logistic multilevel model predicting confidence in the courts } \\
\hline & \multicolumn{3}{c}{ non-interactive } & \multicolumn{3}{c}{ interactive } \\
& $\beta$ & S.E. & p-value & $\beta$ & S.E. & p-value \\
\cline { 2 - 7 } & 0.066 & 0.009 & 0.000 & 0.084 & 0.015 & 0.000 \\
authoritarianism & 0.065 & 0.042 & 0.118 & 0.086 & 0.044 & 0.051 \\
threat & & & & & & \\
& -- & -- & -- & -0.038 & 0.026 & 0.135 \\
auth * threat & & & & & & \\
& -0.001 & 0.001 & 0.202 & -0.001 & 0.001 & 0.196 \\
age & 0.033 & 0.009 & 0.000 & 0.033 & 0.009 & 0.000 \\
education & 0.082 & 0.006 & 0.000 & 0.082 & 0.006 & 0.000 \\
income & 0.084 & 0.025 & 0.001 & 0.084 & 0.025 & 0.001 \\
sex & & & & & & \\
& -0.378 & 0.175 & 0.031 & -0.387 & 0.175 & 0.027 \\
constant & & & & &
\end{tabular}

The right-most model in Table 1 includes an interaction between authoritarianism and perceived threat. Table 2 reports the coefficient (in terms of probability) on authoritarianism across three values of perceived threat $(0,0.50$, and 1$)$. As the p-values on interaction terms in logistic regression models are not necessarily indicative of an insignificant interaction (Mize, 2019), to determine whether there is a significant interaction, I test the difference in slopes between authoritarianism at threat $=0$ and authoritarianism at threat $=1$. In this case, the difference is insignificant $(\Delta=0.008$, s.e. $=0.006, \mathrm{p}=0.133)$. I therefore reject $\mathrm{H}_{2}$ and $\mathrm{H}_{3}$ as there is no significant interaction and therefore no significant movement in the attitudes of the more libertarian toward the more authoritarian.

\section{Trust in Government}

The non-interactive model in Table 3 also supports $\mathrm{H}_{1}$ : there is a positive relationship between authoritarianism and high trust in government. The probability of reporting a high level of trust in government increases from 0.347 at the lowest level of authoritarianism to 0.393 at the 
middle of the scale and to 0.441 at the top of the scale. Increasing from the lowest to the highest level of authoritarianism corresponds to a 0.094 increase in the probability of reporting a high level of trust in the government.

Table 2: marginal effect of authoritarianism on trust across perceived threat

\begin{tabular}{lccccccccc} 
& \multicolumn{3}{c}{ courts } & \multicolumn{3}{c}{ government } & \multicolumn{3}{c}{ parliament } \\
threat $=$ & $\operatorname{Pr}$ & S.E. & p-value & Pr & S.E. & p-value & Pr & S.E. & p-value \\
\hline 0 & 0.018 & 0.003 & 0.000 & 0.014 & 0.003 & 0.000 & 0.010 & 0.003 & 0.001 \\
0.50 & 0.014 & 0.002 & 0.000 & 0.009 & 0.002 & 0.000 & 0.003 & 0.002 & 0.059 \\
1.00 & 0.010 & 0.004 & 0.005 & 0.004 & 0.003 & 0.266 & -0.003 & 0.003 & 0.318 \\
\hline
\end{tabular}

\begin{tabular}{lcccccc} 
& \multicolumn{3}{c}{ armed forces } & \multicolumn{3}{c}{ police } \\
threat $=$ & $\operatorname{Pr}$ & S.E. & p-value & Pr & S.E. & p-value \\
\hline 0 & 0.037 & 0.037 & 0.000 & 0.033 & 0.003 & 0.000 \\
0.50 & 0.027 & 0.002 & 0.000 & 0.021 & 0.002 & 0.000 \\
1.00 & 0.016 & 0.004 & 0.000 & 0.009 & 0.003 & 0.006
\end{tabular}

Note: coefficients are displayed in terms of predicted probabilities

As with trust in the courts, authoritarianism does not appear to interact with threat to predict high trust in government. Table 2 demonstrates a difference in slopes of 0.010 , an insignificant difference ( $\mathrm{s.e} .=0.005, \mathrm{p}=0.059$ ) between the low and the high end of the threat variable. Once again, I reject $\mathrm{H}_{2}$ and $\mathrm{H}_{3}$.

\section{Trust in Parliament}

Trust in parliament follows the emerging trend. In the non-interactive model of Table 4, authoritarianism is positively related to a higher probability of trust in parliament. At the lowest level of authoritarianism there is a 0.321 probability of reporting a high level of trust in parliament. This increases to 0.340 in the middle of the scale and to 0.360 at the top of the scale. 
Moving from the lowest to the highest level of authoritarianism corresponds to a 0.039 probability increase in expressing a high level of trust in parliament.

\begin{tabular}{lcccccc}
\hline \hline \multicolumn{1}{l}{$\begin{array}{l}\text { Table 3: logistic multilevel model predicting confidence in the } \\
\text { government }\end{array}$} & \multicolumn{7}{c}{ non-interactive } & \multicolumn{3}{c}{ interactive } \\
& $\beta$ & S.E. & p-value & $\beta$ & S.E. & p-value \\
\cline { 2 - 7 } & 0.044 & 0.009 & 0.000 & 0.067 & 0.015 & 0.000 \\
authoritarianism & 0.200 & 0.042 & 0.000 & 0.226 & 0.044 & 0.000 \\
threat & & & & & & \\
auth * threat & -- & -- & -- & -0.050 & 0.025 & 0.051 \\
& & & & & & \\
age & 0.005 & 0.001 & 0.000 & 0.005 & 0.001 & 0.000 \\
education & 0.018 & 0.009 & 0.049 & 0.018 & 0.009 & 0.044 \\
income & 0.064 & 0.006 & 0.000 & 0.064 & 0.006 & 0.000 \\
sex & 0.026 & 0.024 & 0.287 & 0.026 & 0.024 & 0.290 \\
& & & & & & \\
constant & 1.061 & 0.157 & 0.000 & 1.072 & 0.157 & 0.000 \\
\hline
\end{tabular}

Unlike with the courts and the government, however, The difference between authoritarianism at threat $=0$ and threat $=1$ is a significant 0.013 (s.e. $=0.005, \mathrm{p}=0.012$ ) indicating a significant interaction effect providing support for $\mathrm{H}_{2}$.

To gain insight into whether the decline in the difference between the more authoritarian and the more libertarian is driven predominantly by libertarians $\left(\mathrm{H}_{3}\right)$, in Figure 1 I plot the predicted probabilities of those at specific values of authoritarianism (authoritarianism=-3 and +3 ) reporting a high level of trust in the parliament over the range of perceived threat. The line for the authoritarians $(+3)$ begins at a probability of 0.345 when threat $=0$ and increases slightly, but insignificantly $(\Delta=0.013$, s.e. $=0.016, \mathrm{p}=0.395)$ to 0.358 when threat $=1$. The line for the libertarians $(-3)$ begins at a probability of 0.286 when threat $=0$ and increases to 0.379 when threat $=1$, an increase of 0.092 (s.e. $=0.020, p<0.001)$; a substantive and significant difference. In 
support of $\mathrm{H}_{3}$, there is a clear decline in the difference in trust between the more authoritarian and the more libertarian and this decline is driven by the greater slope for the latter.

\begin{tabular}{|c|c|c|c|c|c|c|}
\hline \multicolumn{7}{|c|}{ Table 4: logistic multilevel model predicting confidence in parliament } \\
\hline & \multicolumn{3}{|c|}{ non-interactive } & \multicolumn{3}{|c|}{ interactive } \\
\hline & $\beta$ & S.E. & p-value & $\beta$ & S.E. & p-value \\
\hline authoritarianism & 0.019 & 0.009 & 0.031 & 0.051 & 0.015 & 0.001 \\
\hline threat & 0.234 & 0.043 & 0.000 & 0.269 & 0.045 & 0.000 \\
\hline auth $*$ threat & -- & -- & -- & -0.068 & 0.026 & 0.010 \\
\hline age & 0.005 & 0.001 & 0.000 & 0.004 & 0.001 & 0.000 \\
\hline education & 0.028 & 0.009 & 0.003 & 0.029 & 0.009 & 0.002 \\
\hline income & 0.060 & 0.006 & 0.000 & 0.060 & 0.006 & 0.000 \\
\hline sex & -0.016 & 0.025 & 0.516 & -0.017 & 0.025 & 0.509 \\
\hline constant & -1.332 & 0.168 & 0.000 & -1.346 & 0.168 & 0.000 \\
\hline
\end{tabular}

\section{Trust in the Armed Forces}

The non-interactive model in Table 5 demonstrates that authoritarianism is positively related to trust in the armed forces. The probability of the most libertarian reporting a high level of trust in the armed forces is 0.459 . This increases to 0.604 among those in the middle of the scale and 0.733 among the most authoritarian. The most authoritarian are $\sim 27 \%$ more likely to report high trust in the armed forces than are the most libertarian.

Table 2 also reports a fairly substantial difference between the slopes on authoritarianism across the range of threat for trust in the armed forces. The 0.021 difference in slopes is significant $(0.005, \mathrm{p}<0.001)$, providing support for $\mathrm{H}_{2}$. 


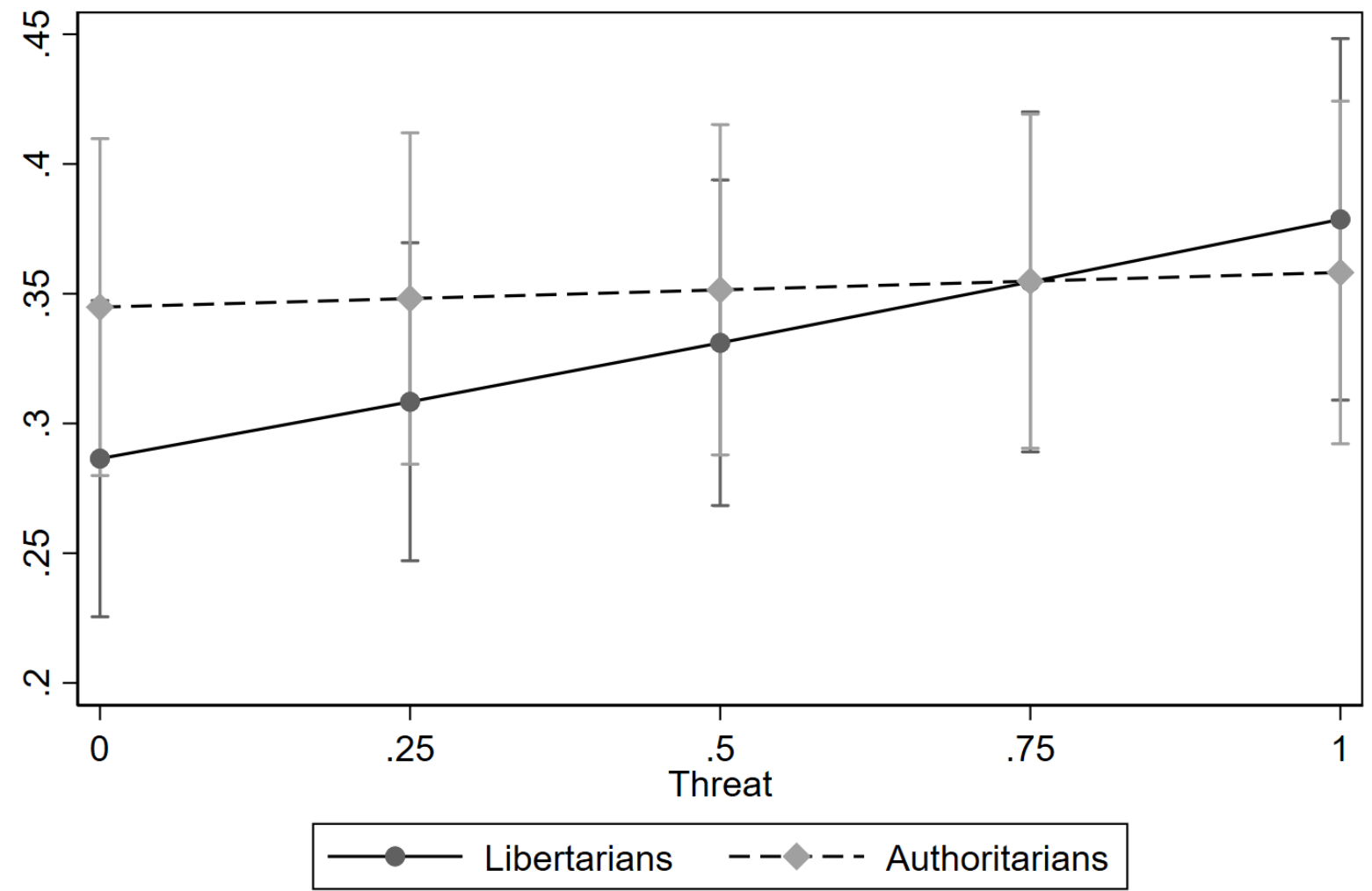

Figure 1: Difference in confidence in parliament among authoritarians and libertarians across the range of threat.

As with the above, in Figure 2 I plot the predicted probabilities of those at specific values of authoritarianism reporting a high level of trust in the armed forces over the range of perceived threat. The line for the authoritarians begins at a probability of 0.681 when threat $=0$ and barely increases to 0.686 when threat $=1(\Delta=0.006$, s.e. $=0.015, p=0.717)$. The line for the libertarians begins at a probability of 0.454 when threat $=0$ and increases to 0.588 when threat $=1$, a significant and substantive increase of 0.134 (s.e. $=0.023$, $\mathrm{p}<0.001$ ). Supporting $\mathrm{H}_{3}$, there is a clear decrease in the difference in trust between the more authoritarian and the more libertarian across the range of threat driven by the more libertarian. 


\begin{tabular}{|c|c|c|c|c|c|c|}
\hline \multirow{4}{*}{$\begin{array}{l}\text { authoritarianism } \\
\text { threat }\end{array}$} & \multicolumn{3}{|c|}{ non-interactive } & \multicolumn{3}{|c|}{ interactive } \\
\hline & $\beta$ & S.E. & p-value & $\beta$ & S.E. & $\mathrm{p}$-value \\
\hline & 0.133 & 0.009 & 0.000 & 0.178 & 0.015 & 0.000 \\
\hline & 0.272 & 0.043 & 0.000 & 0.322 & 0.046 & 0.000 \\
\hline auth $*$ threat & -- & -- & -- & -0.098 & 0.027 & 0.000 \\
\hline age & 0.004 & 0.001 & 0.000 & 0.004 & 0.001 & 0.000 \\
\hline education & -0.032 & 0.010 & 0.001 & -0.031 & 0.010 & 0.002 \\
\hline income & 0.054 & 0.007 & 0.000 & 0.054 & 0.007 & 0.000 \\
\hline sex & -0.141 & 0.026 & 0.000 & -0.141 & 0.026 & 0.000 \\
\hline constant & 0.200 & 0.166 & 0.228 & 0.086 & 0.172 & 0.617 \\
\hline
\end{tabular}

Dependent Variable: Confidence in the Armed Forces

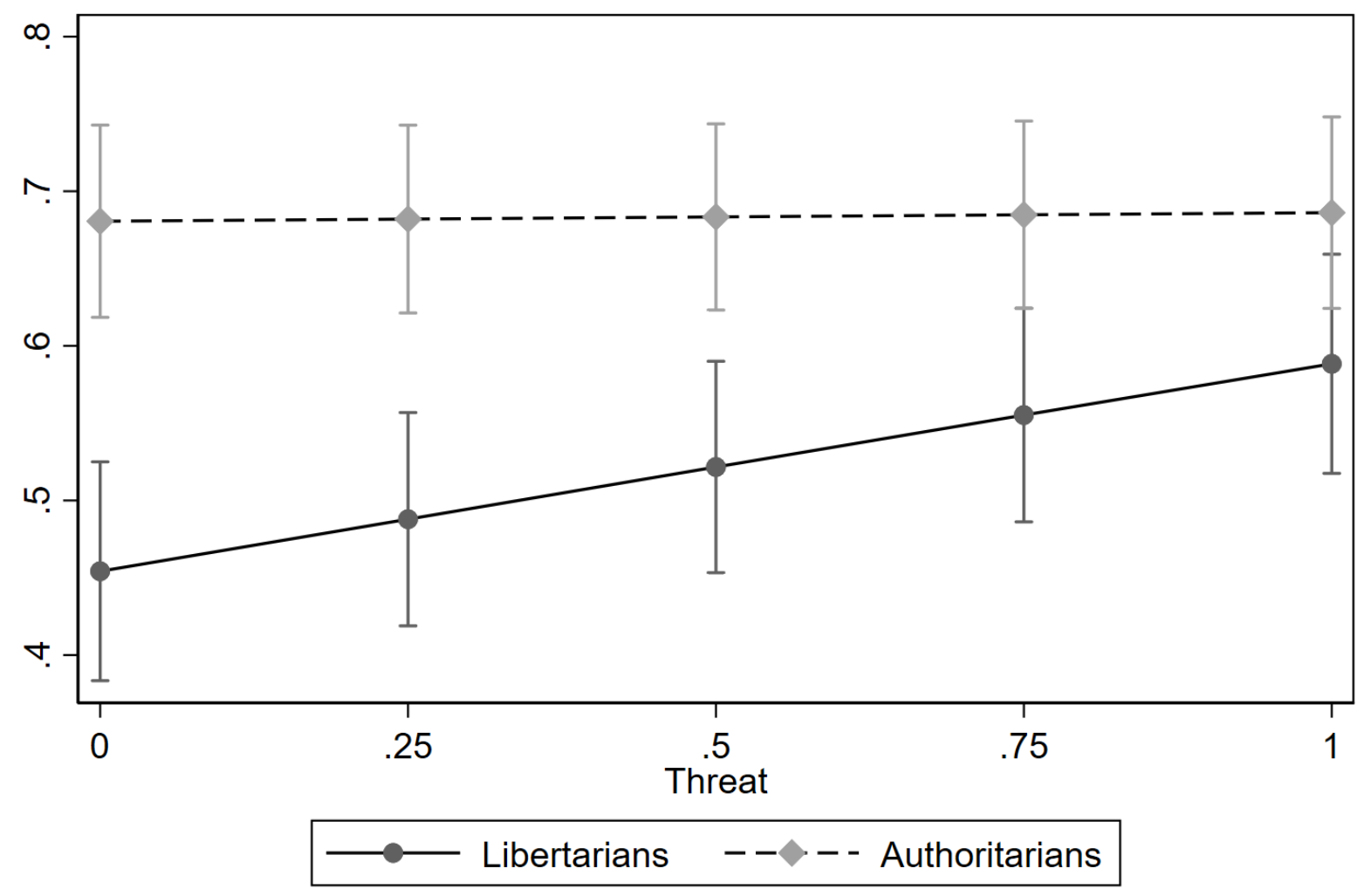

Figure 2: Difference in confidence in the armed forces among authoritarians and libertarians across the range of threat. 


\section{Trust in the Police}

Trust in the police follows a similar pattern to trust in the armed forces. The noninteractive model in Table 6 demonstrates a positive relationship between authoritarianism and trust in the police. Table 2 indicates a rise from a probability of 0.470 when authoritarianism is at its lowest, to a probability of 0.581 at the midpoint of the scale, to a probability of 0.685 when authoritarianism is at its highest. The most authoritarian are $\sim 22 \%$ more likely to report a high level of trust in the police than are the most libertarian.

\begin{tabular}{|c|c|c|c|c|c|c|}
\hline \multicolumn{7}{|c|}{ Table 6: logistic multilevel model predicting confidence in the police } \\
\hline & \multicolumn{3}{|c|}{ non-interactive } & \multicolumn{3}{|c|}{ interactive } \\
\hline & $\beta$ & S.E. & p-value & $\beta$ & S.E. & p-value \\
\hline authoritarianism & 0.102 & 0.009 & 0.000 & 0.154 & 0.015 & 0.000 \\
\hline threat & 0.189 & 0.042 & 0.000 & 0.245 & 0.044 & 0.000 \\
\hline auth $*$ threat & -- & -- & -- & -0.109 & 0.026 & 0.000 \\
\hline age & 0.006 & 0.001 & 0.000 & 0.006 & 0.001 & 0.000 \\
\hline education & 0.012 & 0.009 & 0.206 & 0.013 & 0.009 & 0.173 \\
\hline income & 0.073 & 0.006 & 0.000 & 0.073 & 0.006 & 0.000 \\
\hline sex & 0.097 & 0.025 & 0.000 & 0.097 & 0.025 & 0.000 \\
\hline constant & -0.258 & 0.166 & 0.120 & -0.281 & 0.167 & 0.091 \\
\hline
\end{tabular}

As with trust in both the parliament and the armed forces, authoritarianism is conditional on threat when predicting trust in the police. Table 2 indicates a decline in the slope on authoritarianism from 0.033 to 0.009 across the range of threat; a significant difference of 0.023 (s.e. $=0.005, \mathrm{p}<0.001$ ) providing support for $\mathrm{H}_{2}$.

Figure 3 plots the probability of reporting a high level of trust in the police for the more libertarian and authoritarian across the range of perceived threat. As with Figures 1 and 2, Figure 
3 illustrates a fairly flat line for the more authoritarian (decreasing non-significantly from 0.653 to $0.636 ; \Delta=0.017$, s.e. $=0.016, p=0.279)$ and a steadily increasing line for the more libertarian, increasing from 0.455 when threat $=0$ and 0.579 when threat $=1$, a significant difference of 0.125 (s.e. $=0.022, \mathrm{p}<0.001)$. Once again, the more libertarian are driving the negative interaction, providing support for $\mathrm{H}_{3}$.

Dependent Variable: Confidence in the Police

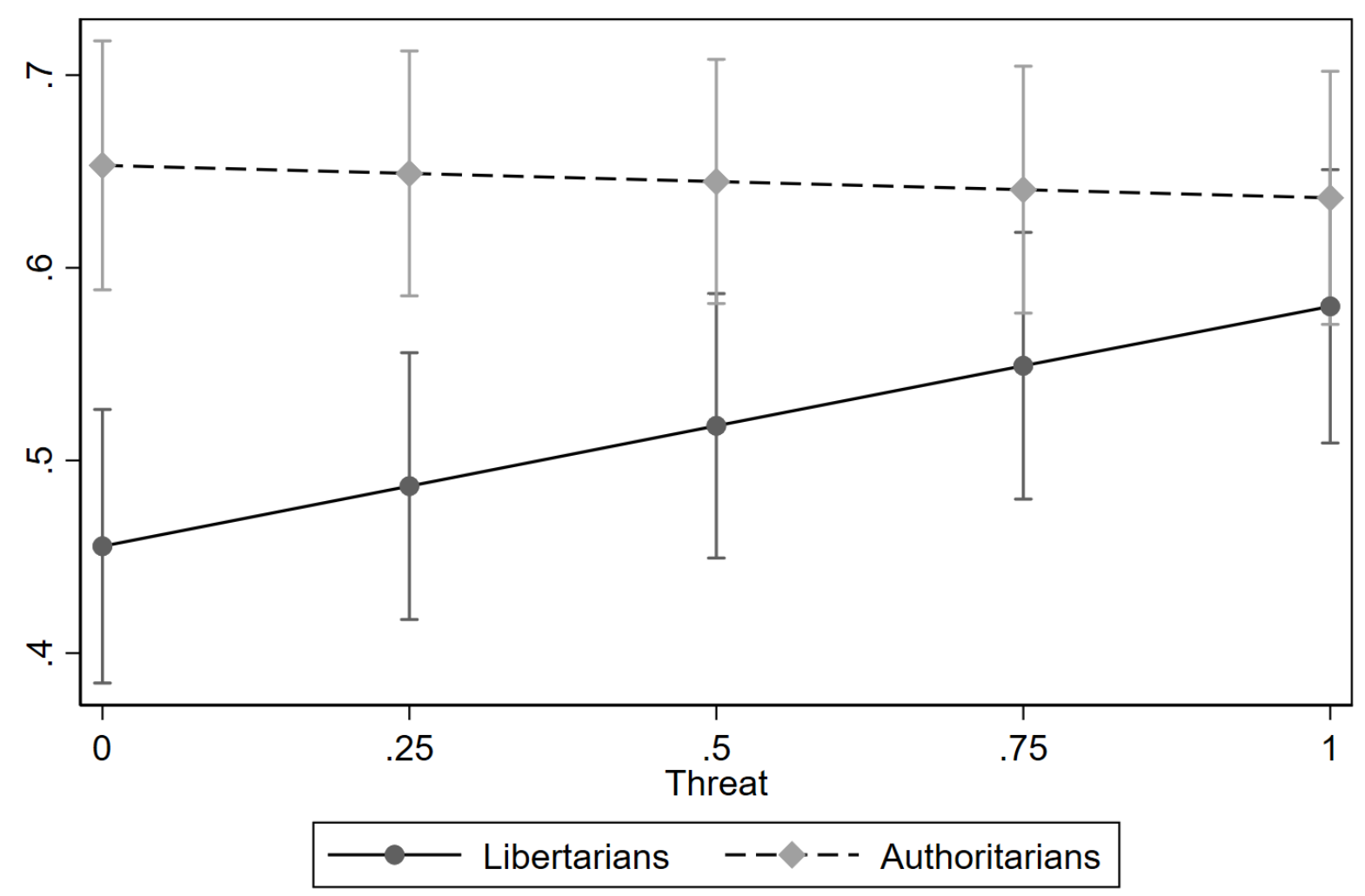

Figure 3: Difference in confidence in the police among authoritarians and libertarians across the range of threat.

Hypothesis 4 suggests that the conditional relationship between authoritarianism and threat driven by the more libertarian will only apply to those institutions whose reason for being is to protect the ingroup from threat. In my discussion of the measurement of threat and trust in institutions I argue that the armed forced and the police are the institutions most likely to be seen 
as most directly responsible for protecting the ingroup from those threats considered here. This is borne out in the above analyses. There is a significant and substantive negative interaction between authoritarianism and threat when predicting trust in the armed forces and the police. In both cases, this negative interaction is driven by the more libertarian.

I also proposed that the parliament and government may also be perceived to be responsible for protecting society, though indirectly via policy and legislation. While this is borne out for trust in parliament, the relationship falls short of conventional standards of significance for trust in government. The courts, as suggested, also do not demonstrate an increase in trust from the more libertarian in response to threat. The analyses here do find evidence supporting $\mathrm{H}_{4}$.

\section{Discussion}

A recent reconceptualization of authoritarianism argues that authoritarianism is a predisposition concerned with the tradeoff between social conformity and individual autonomy. This predisposition reacts with perceived threat to the wellbeing of the ingroup to produce conservative socio-cultural attitudes. For those on the authoritarian side of this predisposition, who prioritize social conformity over individual autonomy, specific threats do little to alter their already conservative socio-cultural attitudes. For those on the libertarian side of this predisposition, who prioritize individual autonomy over social conformity, specific threat has quite a different result: when those with this orientation perceive a threat to the wellbeing of their ingroup, their normally liberal attitudes shift to become more conservative; in some cases to the point where they converge with their more authoritarian brethren. 
This research examines whether the above conditional relationship translates through to trust in political institutions. One of the original concerns of the authoritarianism literature was the willingness of certain individuals to blindly submit to authority. Though the 'agentic state' idea underlying the 'banality of evil' thesis (Arendt, 1964; Milgram, 1974) has been undermined by recent research (e.g., Haslam \& Reicher, 2007; Haslam, Reicher, \& Platow, 2011), there is still the question of why some people more readily submit to morally questionable leadership than others. In this article, in a first step toward uncovering how this values-based conceptualization of authoritarianism relates to authority relations, I look at individual trust toward five political institutions.

Multilevel analyses of data from 25 democratic countries find that authoritarianism is positively related to trust in the armed forces, courts, government, parliament, and the police. This aligns with theoretical expectations from both lines of research into authoritarianism (both the older attitudinal and the newer values-based). However, the theory of a 'libertarian dynamic', where threat induces a conservative shift among the more libertarian, suggests that authoritarianism can interact with threat to temporarily change attitudes toward authorities (Hetherington \& Weiler, 2009). I expect that the relationship between authoritarianism and trust in political institutions will change conditional on respondents' perceived threat. I expect that the more libertarian are predisposed to trust political institutions, who by their very nature undermine individual autonomy in favor of social conformity, less than are authoritarians. And that when libertarians feel threatened they become more trusting of those institutions meant to mitigate the perceived threat; in this case, due to the particular nature of the threat measure used here, the armed forces and police in particular. 
As hypothesized, the libertarian dynamic is apparent when predicting trust in some institutions but not others. There is no interaction between authoritarianism and threat when predicting trust in courts, nor, contrary to expectations, is there any interaction when predicting trust in government. For the parliament, the armed forces, and the police, those institutions specifically mandated to deal with threats to society, the interaction does appear, and in the expected pattern. The more authoritarian demonstrate little difference in trust regardless of perceived threat. The more libertarian, on the other hand, vary depending on their threat profile: those who perceive more threat are much more likely to report a higher level of trust in the parliament, the armed forces, and the police than those who perceive less threat.

This distinction in whether the relationship between authoritarianism and trust in the various political institutions is conditional on threat or not perhaps raises more questions than it answers. One fairly obvious and rather important question is whether these findings are a result of the type of threat I consider in this research. The threat scale is composed of items that are at least partially existential in nature. Would a more normatively-oriented scale condition these relationship differently? Unfortunately, the WVS does not contain any clearly normativelyoriented threat items to examine this possibility.

The more normative discussions in the authoritarianism literature often worry over the potential threat that the more authoritarian pose to liberal-democratic governance (e.g., Altemeyer, 1996; MacWilliams, 2016; Stenner, 2005). This more recent values-oriented line of the authoritarianism research indicates that the more libertarian, when threatened, may be just as great a threat to liberal democracy as their more authoritarian brethren. The underlying problem for liberal-democratic governance, may, therefore, be perceived threat more than an authoritarian or libertarian predisposition. It is threat that provokes intolerant, punitive, and parochial attitudes 
and it is threat that may encourage us to support and trust those willing to turn those attitudes into action via legislative, police, or military action.

Perhaps more interestingly, many theorists of political trust argue that trust in regime institutions is essential for maintaining the stability of both democratic and non-democratic governance. In which case, it is the more authoritarian that may bolster the stability of any system of governance, liberal-democratic systems included. Returning to Almond and Verba's (1963) observation that more subject-oriented (and deferential) political cultures are needed to maintain the stability of democracies, the more libertarian, with their greater distrust of political institutions may serve to destabilize those institutions via their demands for greater voice and autonomy (Dunn et al., 2017; Welzel, 2013). From an optimistic standpoint (for supporters of liberal-democratic governance), distrust toward democratic political institutions may be rooted in the demand for an even greater degree of liberal-democracy rather than an increasing cynicism toward such (e.g., Dalton \& Welzel, 2014; Norris, 1999a; Welzel, 2013). For the more skeptical, greater distrust in governing institutions may also lead to a more populist orientation toward the political, and when combined with enough out-group resentment, fear, or out-right hatred, result in an illiberal reaction to liberal-democratic politics (e.g., Muis \& Immerzeel, 2017; Norris \& Inglehart, 2019; Posner, 2017); a concern that is prominent in both academic literature and popular discourse. 


\section{References}

Adorno, T. W., Frenkel-Brunswik, E., Levinson, D. J., \& Sanford, R. N. (1950). The authoritarian personality (1st ed.). New York: Harper.

Almond, G. A., \& Verba, S. (1963). The Civic Culture: Political attitudes and democracy in five nations. Newbury Park, Calif.: Sage Publications.

Altemeyer, B. (1996). The authoritarian specter. Cambridge, MA: Harvard University Press.

Altemeyer, B. (2004). Highly Dominating, Highly Authoritarian Personalities. Journal of Social Psychology, 144(4), 421-447.

André, S. (2014). Does Trust Mean the Same for Migrants and Natives? Testing Measurement Models of Political Trust with Multi-group Confirmatory Factor Analysis. Social Indicators Research, 115(3), 963-982.

Arendt, H. (1964). Eichmann in Jerusalem: A report on the banality of evil (Revised and Enlarged Edition ed.). New York: The Viking Press.

Arikan, G., \& Sekercioglu, E. (2019). Authoritarian Predispositions and Attitudes Towards Redistribution. Political Psychology, 40(5), 1099-1118.

Asbrock, F., \& Fritsche, I. (2013). Authoritarian Reactions to Terrorist Threat: Who is being threatened, the Me or the We? International Journal of Psychology, 48(1), 35-49.

Bilsky, W., Gollan, T., Roccas, S., Grad, H., Teixeira, M. L. M., Rodriguez, M., .. Segal-Caspi, L. (2015). On the Relative Importance of Personal Values. Journal of Individual Differences, 36(2), 119-129.

Bonanno, G. A., \& Jost, J. T. (2006). Conservative Shift Among High-Exposure Survivors of the September 11th Terrorist Attacks. Basic and Applied Social Psychology, 28(4), 311-323. 
Chanley, V. A. (2002). Trust in Government in the Aftermath of 9/11: Determinants and Consequences. Political Psychology, 23(3), 469-483.

Cieciuch, J., Davidov, E., Algesheimer, R., \& Schmidt, P. (2018). Testing for Approximate Measurement Invariance of Human Values in the European Social Survey. Sociological Methods \& Research, 47(4), 665-686.

Cohrs, J. C., Kielmann, S., Maes, J., \& Moschner, B. (2005). Effects of Right-Wing Authoritarianism and Threat from Terrorism on Restriction of Civil Liberties. Analyses of Social Issues and Public Policy, 5(1), 263-276.

Dalton, R. J., \& Welzel, C. (Eds.). (2014). The Civic Culture Transformed: From allegiant to assertive citizens. New York, NY: Cambridge University Press.

Devos, T., Spini, D., \& Schwartz, S. H. (2002). Conflicts Among Human Values and Trust in Institutions. British Journal of Social Psychology, 41, 481-494.

Doty, R. M., Peterson, B. E., \& Winter, D. G. (1991). Threat and authoritarianism in the United States, 1978-1987. Journal of Personality \& Social Psychology, 61(4), 629-640.

Duckitt, J. (1989). Authoritarianism and group identification: A new view of an old construct. Political Psychology, 10(1), 63-84.

Duckitt, J. (2013). Introduction to the Special Section on Authoritarianism in Societal Context: The role of threat. International Journal of Psychology, 48(1), 1-5.

Dunn, K. (2014). Authoritarianism and Intolerance Under Autocratic and Democratic Regimes. Journal of Social and Political Psychology, 2(1), 220-241.

Dunn, K. (2015). Preference for Radical Right-wing Populist Parties among Exclusivenationalists and Authoritarians. Party Politics, 21(3), 367-380. 
Dunn, K., Griffiths, E., Lamb, S., Shortt, R., \& Theochari, E. (2017). The Human Empowerment Sequence and the Development of Libertarian Values: A Theoretical and Empirical Adjustment to the Human Empowerment Sequence. Journal of Cross-Cultural Psychology, 48(5), 771-789.

Dunn, K., \& Singh, S. P. (2014). Pluralistic Conditioning: Social tolerance and effective democracy. Democratization, 21(1), 1-28.

Dunn, K., Spaiser, V., \& Dodds, H. J. (2020). The Role of Threat in the Human Empowerment Sequence. https://doi.org/10.31234/osf.io/3zun4.

Dunn, K., \& Thornton, J. (2019). Indifference and Ambivalence in the concept of Authoritarianism and the Consequences for Tolerance and Trust in Others. Paper presented at the 90th Annual Conference of the Southern Political Science Association, Austin, Texas.

Easton, D. (1975). A Re-Assessment of the Concept of Political Support. British Journal of Political Science, 5(4), 435-457.

Feldman, S. (2003). Enforcing social conformity: A theory of authoritarianism. Political Psychology, 24(1), 41-74.

Feldman, S. (2013). Comments on: Authoritarianism in Social Context: The role of threat. International Journal of Psychology, 48(1), 55-59.

Feldman, S., \& Stenner, K. (1997). Perceived threat and authoritarianism. Political Psychology, 18(4), 741-770.

Freedomhouse.org. (2018). Freedom in the World 2018. Online: Freedom House. 
Frenkel-Brunswik, E., Levinson, D. J., \& Sanford, R. N. (1947). The Antidemocratic Personality. In E. E. Maccoby, T. M. Newcomb \& E. L. Hartley (Eds.), Readings in Social Psychology. New York: Henry Holt \& Co.

Fromm, E. (1941). Escape from freedom. New York: Farrar \& Rinehart.

Gadarian, S. K. (2010). The Politics of Threat: How Terrorism News Shapes Foreign Policy Attitudes. The Journal of Politics, 72(2), 469-483.

Haslam, S. A., \& Reicher, S. (2007). Identity Entrepreneurship and the Consequences of Identity Failure: The Dynamics of Leadership in the BBC Prison Study. Social Psychology Quarterly, 70(2), 125-147.

Haslam, S. A., Reicher, S., \& Platow, M. (2011). The New Psychology of Leadership: Identity, influence, and power. Hove; New York: Psychology Press.

Hetherington, M. J. (1998). The Political Relevance of Political Trust. The American Political Science Review, 92(4), 791-808.

Hetherington, M. J. (1999). The Effect of Political Trust on the Presidential Vote, 1968-96. The American Political Science Review, 93(2), 311-326.

Hetherington, M. J. (2005). Why Trust Matters: Declining political trust and the demise of American liberalism. Princeton, NJ: Princeton University Press.

Hetherington, M. J., \& Rudolph, T. J. (2015). Why Washington Won't Work. Chicago, IL: The University of Chicago Press.

Hetherington, M. J., \& Suhay, E. (2011). Authoritarianism, threat, and Americans' support for the War on Terror. American Journal of Political Science, 55(3), 546-560.

Hetherington, M. J., \& Weiler, J. D. (2009). Authoritarianism and Polarization in American Politics. Cambridge; New York: Cambridge University Press. 
Hooghe, M., \& Marien, S. (2013). A Comparative Analysis of the Relation between Political Trust and Forms of Political Participation in Europe. European Societies, 15(1), 131-152.

Hooghe, M., Marien, S., \& Pauwels, T. (2011). Where Do Distrusting Voters Turn if There is No Viable Exit or Voice Option? The Impact of Political Trust on Electoral Behaviour in the Belgian Regional Elections of June 2009. Government and Opposition, 46(2), 245-273.

Huddy, L., Feldman, S., Taber, C., \& Lahav, G. (2005). Threat, Anxiety, and Support of Antiterrorism Policies. American Journal of Political Science, 49(3), 593-608.

Inglehart, R., Haerpfer, C., Moreno, A., Welzel, C., Kizilova, K., Medrano, J. D., . . Puranen, B. (2014). World Values Survey: Round Six - Country-Pooled Datafile 2010-2014.

Jost, J. T., Glaser, J., Kruglanski, A. W., \& Sulloway, F. J. (2003). Political Conservatism as Motivated Social Cognition. Psychological Bulletin, 129(3), 339-375.

Jost, J. T., Napier, J. L., Thorisdottir, H., Gosling, S. D., Palfai, T. P., \& Ostafin, B. (2007). Are Needs to Manage Uncertainty and Threat Associated With Political Conservatism or Ideological Extremity? Personality and Social Psychology Bulletin, 33(7), 989-1007.

Lagacé, C. B., \& Gandhi, J. (2015). Authoritarian Institutions. In J. Gandhi \& R. Ruiz-Rufino (Eds.), Routledge Handbook of Comparative Political Institutions. New York, NY: Routledge.

Levi, M., \& Stoker, L. (2000). Political Trust and Trustworthiness. Annual Review of Political Science, 3(1), 475-507.

MacWilliams, M. C. (2016). Who Decides When The Party Doesn't? Authoritarian Voters and the Rise of Donald Trump. PS: Political Science \& Politics, 49(4), 716-721. 
Maio, G. R., Pakizeh, A., Cheung, W.-Y., \& Rees, K. J. (2009). Changing, Priming, and Acting on Values: Effects via Motivational Relations in a Circular Model Journal of Personality and Social Psychology, 97(4), 699-715.

Marien, S., \& Hooghe, M. (2011). Does political trust matter? An empirical investigation into the relation between political trust and support for law compliance. European Journal of Political Research, 50(2), 267-291.

Matthews, M., Levin, S., \& Sidanius, J. (2009). A Longitudinal Test of the Model of Political Conservatism as Motivated Social Cognition. Political Psychology, 30(6), 921-936.

McLaren, L. M. (2003). Anti-immigrant prejudice in Europe: Contact, threat perception, and preferences for the exclusion of migrants. Social Forces, 81(3), 909-936.

Milgram, S. (1974). Obedience to Authority: An experimental view. New York: Harper \& Row.

Mize, T. D. (2019). Best Practices for Estimating, Interpreting, and Presenting Nonlinear Interaction Effects Sociological Science, 6(4), 81-117.

Muis, J., \& Immerzeel, T. (2017). Causes and consequences of the rise of populist radical right parties and movements in Europe. Current Sociology, 65(6), 0011392117717294.

Nail, P. R., McGregor, I., Drinkwater, A. E., Steele, G. M., \& Thompson, A. W. (2009). Threat causes liberals to think like conservatives. Journal of Experimental Social Psychology, 45(4), 901-907.

Norris, P. (1999a). Critical Citizens: Global support for democratic government. Oxford; New York: Oxford University Press.

Norris, P. (1999b). Introduction: The growth of critical citizens? In P. Norris (Ed.), Critical Citizens: Global support for democratic government (pp. 1-27). New York, NY: Oxford University Press. 
Norris, P., \& Inglehart, R. (2019). Cultural Backlash: Trump, Brexit, and Authoritarian Populism. Cambridge: Cambridge University Press.

Oesterreich, D. (2005). Flight into Security: A New Approach and Measure of the Authoritarian Personality. Political Psychology, 26(2), 275-298.

Posner, E. A. (2017). Liberal Internationalism and the Populist Backlash. Arizona State Law Journal, 49(Special Issue), 795-819.

Riek, B. M., Mania, E. W., \& Gaertner, S. L. (2006). Intergroup Threat and Outgroup Attitudes: A Meta-Analytic Review. Personality and Social Psychology Review, 10(4), 336-353.

Riskind, J. H. (1997). Looming vulnerability to threat: A cognitive paradigm for anxiety. Behaviour Research and Therapy, 35(8), 685-702.

Sales, S. M. (1973). Threat as a factor in authoritarianism: An analysis of archival data. Journal of Personality \& Social Psychology, 28(1), 44-57.

Schneider, I. (2017). Can We Trust Measures of Political Trust? Assessing Measurement Equivalence in Diverse Regime Types. Social Indicators Research, 133(3), 963-984.

Schwartz, S. H. (1992). Universals in the Content and Structure of Values: Theoretical advances and empirical tests in 20 countries. In M. P. Zanna (Ed.), Advances in experimental social psychology (Vol. 25, pp. 1-65). San Diego, CA.: Academic Press.

Schwartz, S. H. (2007). Value Orientations: Measurement, antecedents and consequences across nations. In R. Jowell, C. Roberts, R. Fitzgerald \& G. Eva (Eds.), Measuring Attitudes Cross-Nationally: Lessons from the European Social Survey. London: Sage Publications Ltd.

Schwartz, S. H. (2012). An Overview of the Schwartz Theory of Basic Values. Online Readings in Psychology and Culture, 2(1), 1-20. 
Schwartz, S. H., \& Bilsky, W. (1987). Toward A Universal Psychological Structure of Human Values. Journal of Personality \& Social Psychology, 53(3), 550-562.

Schwartz, S. H., \& Boehnke, K. (2004). Evaluating the structure of human values with confirmatory factor analysis. Journal of Research in Personality, 38(3), 230-255.

Schwartz, S. H., Cieciuch, J., Vecchione, M., Davidov, E., Fischer, R., Beierlein, C., .. . Konty, M. (2012). Refining the Theory of Basic Individual Values. Journal of Personality \& Social Psychology, 103(4), 663-688.

Schwartz, S. H., Melech, G., Lehmann, A., Burgess, S., Harris, M., \& Owens, V. (2001). Extending the Cross-Cultural Validity of the Theory of Basic Human Values with a Different Method of Measurement. Journal of Cross-Cultural Psychology, 32(5), 519542.

Stenner, K. (2005). The Authoritarian Dynamic. New York, NY: Cambridge University Press. Tyler, T. R. (1997). The Psychology of Legitimacy: A Relational Perspective on Voluntary Deference to Authorities. Personality and Social Psychology Review, 1(4), 323-345.

Tyler, T. R., \& Lind, E. A. (1992). A Relational Model of Authority in Groups. In P. Z. Mark (Ed.), Advances in experimental social psychology (Vol. Volume 25, pp. 115-191). San Diego, CA: Academic Press.

Weiner, E., \& Federico, C. M. (2017). Authoritarianism, Institutional Confidence, and Willingness to Engage in Collective Action. Personality and Social Psychology Bulletin, 43(3), 392-406.

Welzel, C. (2013). Freedom Rising: Human empowerment and the quest for emancipation. New York, NY: Cambridge University Press. 
Zhang, Q., \& Wang, E. (2010). Local Political Trust: The Antecedents and Effects on Earthquake Victims' Choice for Allocation of Resources. Social Behavior and Personality: an international journal, 38(7), 929-939.

Ziller, C., \& Schübel, T. (2015). "The Pure People" versus "the Corrupt Elite"? Political Corruption, Political Trust and the Success of Radical Right Parties in Europe. Journal of Elections, Public Opinion and Parties, 1-19. 